\title{
PENGEMBANGAN APLIKASI PEMILIHAN KOST DI KOTA MALANG DENGAN METODE AHP DAN PROMETHEE
}

\author{
Budi Harijanto², Nurul Asqiyah Tamara ${ }^{1}$, Yuri Ariyanto ${ }^{3}$ \\ 1,2,3 Jurusan Teknologi Informasi, ${ }^{2}$ Program Studi Teknik Informatika ${ }^{3}$ Politeknik Negeri Malang \\ budi.hijet@gmail.com, ${ }^{2}$ asqiyahtamara@gmail.com, ${ }^{3}$ yuri.arianto@polinema.ac.id
}

\begin{abstract}
Abstrak
Banyaknya orang yang membutuhkan informasi rumah kost, sementara untuk mendapatkan informasi rumah kost saat ini yaitu dengan cara mendatangi lokasi tempat kost secara langsung. Dari masalah tersebut, diperlukan aplikasi untuk memudahkan dalam pencarian kost yang mampu menyediakan informasi tentang data kost dan penyewaan rumah kost secara online. Peneliti merancang dan membangun website rekomendasi tempat kost dengan aplikasi kost online menggunakan metode AHP dan Promethee.Perhitungan dalam penerapan metode ahp untuk mendapatkan bobot dalam kriteria pencarian rumah kost, dan Metode Promethee digunakan dalam pencarian rekomendasi rumah kost. Aplikasi ini diharapkan dapat membantu semua orang untuk mendapatkan 5 rekomendasi tempat kost sesuai dengan kriteria yang diinginkan.
\end{abstract}

Kata kunci : AHP, Promethee, pemilihan kost

\section{Pendahuluan}

Kebutuhan informasi tentang rumah kost dan lokasi tempat kost sangat diperlukan untuk mempermudah seseorang dalam mendapatkan kost. Pencarian yang selama ini masih dilakukan dengan cara manual atau mendatangi satu persatu rumah kost. Ternyata tidaklah mudah bagi pencari kost, yang pada umumnya kurang mengetahui tentang daerah rumah kost rantauannya. Banyak kriteria yang menjadi pertimbangan untuk memilih rumah kost dan berbagai pertimbangan dilakukan oleh seorang pencari kost agar mendapatkan rumah kost yang tepat dan sesuai. Hal itu menyebabkan pencari kost harus lebih selektif dalam menentukan pilihan mereka. Dengan memanfaatkan teknologi saat ini menjadikan banyak kemudahan dan manfaat. Seperti halnya traveloka dan agoda yang menampikan informasi terkait tentang hotel tidak pada penyewaan rumah kost.

Berdasarkan permasalahan di atas, akan dibuat "Aplikasi Pemilihan Rumah Kost di Kota Malang Menggunakan Metode AHP dan Promethee" untuk memudahkan pencari kost dalam melakukan pemilihan rumah kost. Pada penelitian ini langkah awal adalah penetapan kriteria-kriteria yang dianggap penting dalam pemilihan kost, Seperti: harga kost, jenis kost, jangka waktu sewa kost dan jarak kost, kemudian digunakan penggabungan metode AHP dan promethee sebagai pendukung model pengambilan keputusan dalam penetapan prioritas suatu sistem pemilihan kost.

Metode AHP digunakan untuk memperoleh bobot relatif dari masing-masing kriteria. Setelah itu dilakukan penentuan nilai dari masing-masing rumah kost, langkah selanjutnya adalah menghitung menggunakan perhitunan menggunakan metode promethee untuk memperoleh urutan prioritas atau rekomendasi rumah kost dari pemilihan kost. Setelah mendapatkan rekomendasi rumah kost, maka akan tampil lokasi kost sebagai fitur tambahan.

\section{Kajian Pustaka}

\subsection{Kos kosan}

Kos-kosan bisa juga disebut rumah penginapan. Itu adalah rumah yang digunakan orang umtuk menginap selama 1 hari atau lebih, dan kadangkadang untuk periode waktu yang lebih lama misalnya: minggu, bulan atau tahunan. Dahulunya, para penginapnya biasanya menggunakan sarana kamar mandi atau cuci, pantry dan ruang makan secara bersama-sama. Namun tahun-tahun belakangan ini, kamar kos-kosan berubah menjadi ruangan yang mempunyai ruang cuci dan fasilitas kamar mandi atau pantry sendiri dan dihuni dalam jangka lama misalnya bulanan atau tahunan. Aslam,(2010)

Selain itu, menurut DINAS PERUMAHAN PROPINSI DKI JAKARTA pengertian tentang Rumah Kost adalah:

Perumahan pemondokan/rumah kost adalah rumah yang penggunaannya sebagian atau seluruhnya dijadikan sumber pendapatan oleh pemiliknya dengan jalan menerima penghuni pemondokan minimal 1 (satu) bulan dengan memungut uang pemondokan. 


\subsection{Metode AHP(Analytic Hierarchy Proses)}

AHP adalah proses yang menggunakan perbandingan berpasangan untuk menentukan faktor dan evaluasi faktor bobot dalam pengambilan keputusan multifaktor. Peralatan utama AHP adalah sebuah hirarki fungsional dengan input utamanya presepsi manusia. Keberadaan hirarki memungkinkan dipecahnya masalah kompleks (tidak terstruktur) dalam sub - sub masalah sehingga menyusunnya menjadi suatu bentuk hirarki. Harsiti,Dkk (2015)

Banyak keunggulan yang dimiliki AHP dalam menjelaskan proses pengambilan keputusan. Salah satunya adalah dapat digambarkan secara grafis sehingga mudah dipahami oleh semua pihak yang terlibat dalam pengambilan keputusan.

Peralatan utama AHP adalah sebuah hierarki fungsional dengan input utamanya adalah persepsi manusia. Keberadaan hierarki memungkinkan dipecahnya masalah kompleks atau tidak terstruktur dalam sub-sub masalah, lalu menyusunnya menjadi suatu bentuk hierarki. Prinsip dasar AHP, antara lain :

a. Membuat hierarki

Sistem yang kompleks bisa dipahami dengan memecahnya menjadi elemen-elemen pendukung, menyusun elemen secara hierarki, dan menggabungkannya.

b. Penilaian kriteria dan alternatif

Kriteria dan alternatif dilakukan dengan perbandingan berpasangan, untuk berbagai persoalan, skala 1 sampai 9 adalah skala terbaik untuk mengekspresikan pendapat. Nilai dan definisi pendapat kualitatif dari skala perbandingan Saaty bisa diukur menggunakan tabel analisis seperti pada table berikut.

Tabel 1 Skala Penilaian Perbandingan Berpasangan

\begin{tabular}{|c|c|}
\hline Nilai & Keterangan \\
\hline 1 & $\begin{array}{l}\text { Kedua elemen sama pentingnya } \\
\text { (equal) }\end{array}$ \\
\hline 3 & $\begin{array}{l}\text { Elemen yang satu sedikit lebih } \\
\text { penting dari pada elemen yang } \\
\text { lainnya (moderate) }\end{array}$ \\
\hline 5 & $\begin{array}{l}\text { Elemen yang satu lebih penting } \\
\text { daripada elemen yang lainnya } \\
\text { (strong) }\end{array}$ \\
\hline 7 & $\begin{array}{l}\text { Satu elemen jelas lebih mutlak } \\
\text { penting daripada } \\
\text { lainnya(very strong) }\end{array}$ \\
\hline 9 & $\begin{array}{l}\text { Satu elemen mutlak penting } \\
\text { daripada elemen lainnya (extreme) }\end{array}$ \\
\hline $2,4,6,8$ & $\begin{array}{l}\text { Nilai-nilai antara dua nilai } \\
\text { pertimbangan yang berdekatan }\end{array}$ \\
\hline $1 /(1-9)$ & $\begin{array}{l}\text { Kebalikan nilai tingkat kepentingan } \\
\text { dari skala } 1-9\end{array}$ \\
\hline
\end{tabular}

c. Synthesis of priority (menentukan prioritas)

Untuk setiap kriteria dan alternarif, perlu dilakukan perbandingan berpasangan (pairwise comparisons). Nilai-nilai perbandingan relatif dari seluruh alternatif kriteria bisa disesuaikan dengan judgement yang telah ditentukan untuk menghasilkan bobot dan prioritas.

\section{d. Logical Consistency (Konsistensi Logis)}

Konsistensi memiliki dua makna. Pertama, objek-objek yang serupa bisa dikelompokkan sesuai dengan keseragaman dan relevansi. Kedua, menyangkut tingkat hubungan antarobjek yang didasarkan pada kriteria tertentu.

Prosedur atau langkah-langkah dalam metode AHP meliputi :

a. Mendefinisikan masalah dan menentukan solusi yang diinginkan, lalu menyusun hierarki dari permasalahan yang dihadapi.

b. Menentukan prioritas elemen.

c. Sintesis.

d. Mengukur konsistensi.

e. Menghitung Consistency Index (CI).

f. Menghitung Rasio Konsistensi/Consistency Ratio.

g. Memeriksa konsistensi hierarki.

Pada tahapan ini dilakukan pemeriksaan terhadap konsistensi penilaian. Bila nilai konsistensi yang didapat menyimpang terlalu jauh dari nilai konsistensi terbaik, maka proses penilaian berpasangan harus diperbaiki atau diulang kembali. Sundarraj(2015);

Rumus untuk menghitung konsistensi adalah sebagai berikut :

$$
\begin{aligned}
& C I=\frac{\left(\lambda_{\max }-n\right)}{(n-1)} \\
& C R=\frac{C I}{R I}
\end{aligned}
$$

Untuk menentukan nilai Random Index (RI) dapat dilihat pada tabel di bawah ini:

Tabel 2 Nilai Random Index (RI)

\begin{tabular}{|l|l|}
\hline $\mathbf{N}$ & $\mathbf{R I}$ \\
\hline 2 & 0.00 \\
\hline 3 & 0.58 \\
\hline 4 & 0.90 \\
\hline 5 & 1.12 \\
\hline 6 & 1.24 \\
\hline 7 & 1.32 \\
\hline 8 & 1.41 \\
\hline 9 & 1.45 \\
\hline 10 & 1.49 \\
\hline 11 & 1.51 \\
\hline 12 & 1.48 \\
\hline 13 & 1.56 \\
\hline 14 & 1.57 \\
\hline 15 & 1.59 \\
\hline
\end{tabular}

\section{Keterangan :}

$\mathrm{N}$ : Ordo matriks 
$\lambda \max :$ Nilai hasil dari penjumlahan konsistensi vector dibagi dengan $\mathrm{n}$

CI (Consistency Index) : Rasio penyimpanan konsistensi

CR (Consistency Ratio) : Rasio Konsistensi

Ri (Random Index) : Indeks Random

\subsection{Metode PROMETHEE}

Metode Promethee (Preference Ranking Organization Method for Enrichment Evaluation) merupakan salah satu metode yang dapat digunakan adalah menentukan urutan (prioritas) dalam analisis multikriteria. Metode Promethee pertama kali dikembangkan oleh JP.Brans dan dipublikasikan pada tahun 1982 pada sebuah konferensi yang diorganisasikan R.Nadeau dan M.Landry di Universitas Laval, Quebec Canada. Lemantara, Dkk (2013).

Metode Promethee dapat dijalankan melalui beberapa tahap, yaitu :

a. Menentukan kriteria-kriteria yang akan digunakan beserta bobot dari masing-masing kriteria.

b. Menentukan semua alternatif yang ada.

c. Menentukan tipe preferensi untuk tiap-tiap kriteria secara tepat. tipe preferensi yang digunakan dalam metode Promethee adalah fungsi keanggotaan himpunan fuzzy. Tipe preferensi ditentukan berdasarkan karakteristik dari kriteria tersebut. Ada enam bentuk tipe preferensi yang sering digunakan, yaitu usual criterion, quasi criterion, criterior with linier preference, level criterion, criterion with linear preference and indifference area dan Gausian criterion.

d. Menghitung preferensi dari tiap-tiap kriteria. Preferensi dari tiap-tiap kriteria dihitung berdasarkan perbandingan antara setiap pasang alternatif yaitu selisih antara nilai evaluasi dari dua buah alternatif terhadap kriteria tertentu. Nilai preferensi berkisar dari nol sampai satu. Preferensi bernilai nol apabila tidak ada perbedaan antara kedua alternatif yang dibandingkan. Preferensi akan bernilai satu apabila alternatif yang satu lebih baik dari alternatif lainnya.

e. Menghitung arah preferensi berdasarkan nilai indeks leaving flow dan entering flow. Untuk setiap alternatif, nilai leaving flow dapat dihitung menggunakan persamaan :

$$
\phi^{+}=\frac{1}{n-1} \sum_{X \in A} \wp(\alpha, \chi)
$$

Sedangkan nilai entering flow dihitung dengan menggunakan persamaan :

$\phi(a)=\frac{1}{n-1} \sum_{X \in A} \wp(\alpha, \chi)$

Dimana :

$$
\begin{aligned}
& \wp(\alpha, \chi)=\text { menunjukkan preferensi alternatif } \\
& \text { a lebih baik dari } \mathrm{x} . \\
& \mathrm{n}=\text { jumlah nilai. }
\end{aligned}
$$

f. Menghitungkan net flow.Net flow dihitung dengan menggunakan persamaan :

$$
\phi=\phi^{+}(a)-\phi^{-}(a)
$$

g. Mengurutkan alternatif berdasarkan net flow . Semakin besar nilai Leaving flow dan semakin kecil Entering flow maka alternatif tersebut memiliki kemungkinan dipilih yang semakin besar. Perangkingan dalam PROMETHEE I dilakukan secara parsial, yaitu didasarkan pada nilai Leaving flow dan Entering flow. Sedangkan PROMETHEE II termasuk perangkingan komplek karena didasarkan pada nilai Net flow masing-masing alternatif yaitu alternatif dengan nilai Net flow lebih tinggi menempati satu rangking yang lebih baik.

\section{Metode Penelitian}

\subsection{Metode Pengambilan Data}

Untuk dapat melakukan analisis yang baik, diperlukan data, serta teori konsep dasar, sehingga kebutuhan data sangat mutlak diperlukan. Adapun metode pengumpulan data dilakukan dengan cara :

a. Observasi (Pengamatan)

Pengumpulan data melalui pengamatan secara langsung pada obyek penelitian. Observasi bertujuan untuk mengamati suatu keadaan sosial sekaligus melakukan pengumpulan data serta mengamati keseluruhan gejala-gejala atau keadaan yang terjadi.

b. Interview (wawancara)

Menurut Estenberg, wawancara merupakan pertemuan pertemuan dua orang untuk bertukar informasi dan ide melalui tanya jawab sehingga dapat dikonstruksikan makna dalam suatu topik tertentu.

c. Skuisioner

Angket atau Kuesioner merupakan suatu pengumpulan data yang dilakukan dengan cara memberi pertanyaan atau pernyataan tertulis kepada responden untuk dijawab. Dalam hal ini penulis memberikan secara serempak angket kepada banyak penyewa kost di daerah kota malang. Responden dalam penelitian ini yaitu pihak anak kost atau penghuni kost. Tujuan pembuatan kuesioner ini adalah untuk mencari data dari seriap kriteria.

\subsection{Metode Pengolahan Data}

Dalam penelitian ini akan menerapkan kombinasi AHP dan Promethee untuk menghasilkan rekomendasi peringkat dari pemilihan kost. Kerangka berpikir yang digunakan dalam penelitian 
ini dapat dilihat pada Gambar 3.1. Pada tahapan pertama diawali dengan proses pemilihan kost dengan proses AHP terlebih dahulu dengan masukan matriks perbandingan berpasangan kriteria. Setelah itu, proses AHP akan menghasilkan keluaran bobot kriteria yang menjadi masukan untuk proses Promethee. Dengan metode Promethee, urutan atau prioritas alternatif akan dihasilkan.

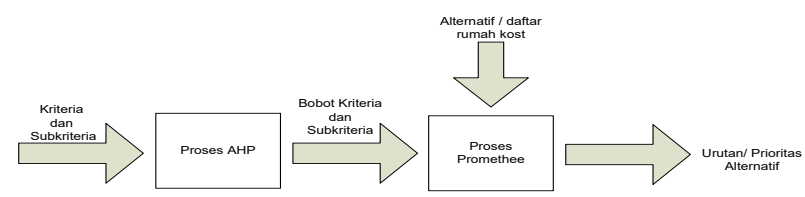

Gambar 1. Skema hirarki

Gambar 1 menunjukan skema hirarki yang dibuat untuk pemilihan rumah kost di Kota Malang, adapun yang menjadi kriteria test untuk menjadi pemilihan rumah kost terdiri jarak dengan kampus, jarak dengan mall, jarak dengan rumah sakit,harga, ukuran dan fasilitas. Pada metode promethee perhitungan dilakukan dengan cara mencari nilai threshold $\mathrm{p}$, q pada masing-masing kriteria. Serta menentukan minimasi dan maksimasi pada setiap kriteria. Karena pada metode promethee terdapat 6 tipe preferensi yang hasil akhirnya bergantung dalam jenis tipe preferensi, penentuan min-maks dan juga threshold yang ditentukan sehingga menghasilkan output berupa urutan rangking tempat kost.

\subsection{WBS}

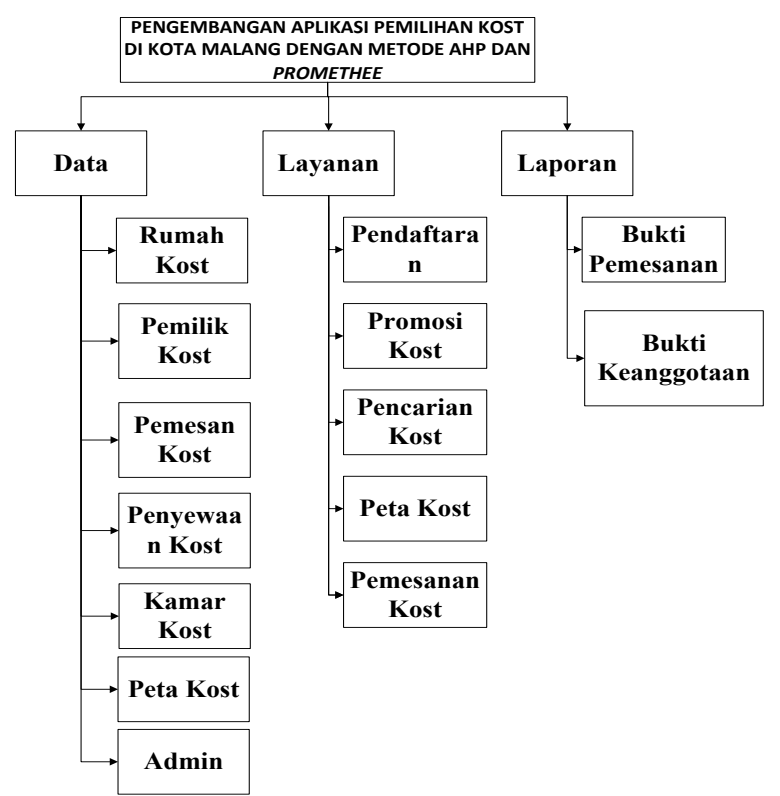

Gambar 2. WBS

\subsection{Usecase}

Use case diagram adalah diagram yang menggambarkan interaksi antara use case dan aktor. Dimana aktor dapat berupa orang, peralatan atau sistem lain yang berinteraksi dengan sistem yang sedang dibangun. Use Case menggambarkan fungsionalitas sistem atau persyaratan - persyaratan yang harus dipenuhi sistem dari pandangan pemakai. Berikut ini adalah Use Case dari pengembangan aplikasi pemilihan rumah kost menggunakan metode AHP dan Promethee:

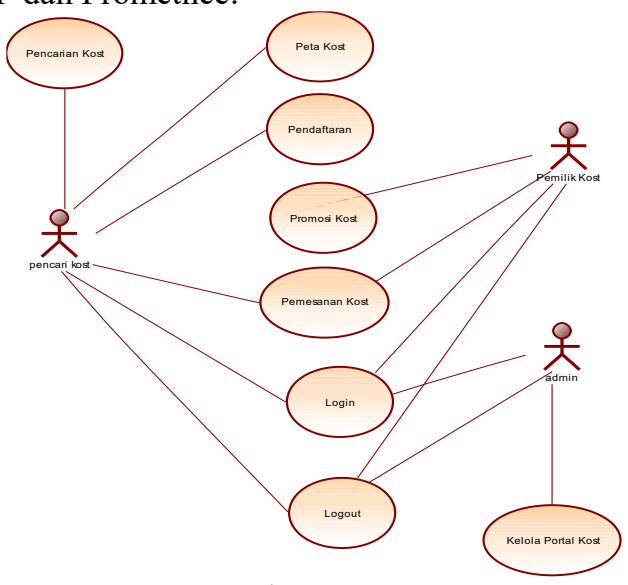

Gambar 3. Use case

\section{Hasil dan Pembahasan}

\subsection{Hasil}

Pada hasil basis data akan dijelaskan mengenai penerapan dari basis data yang digunakan pada sistem. Berdasarkan perancangan yang telah dilakukan, dibuat database yang bernama mawapres yang berisi beberapa tabel, seperti terlihat pada gambar di bawah.

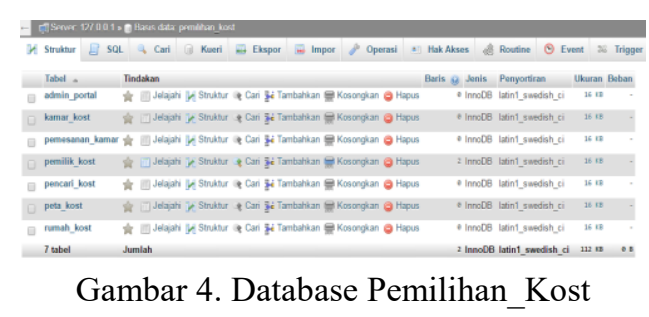

Pada implementasi sistem akan dijabarakan implementasi dari aplikasi rekomendasi tempat kost. Implementasi Halaman User Pencari Kost. Pada halaman awal pencarian kost terdapat menu kategori rumah kost, pencarian dan daftar rumah kost yang dilakukan oleh pencari kost atau penyewa. Implementasi halaman awal pencarian kost akan ditunjukan pada gambar 5 .

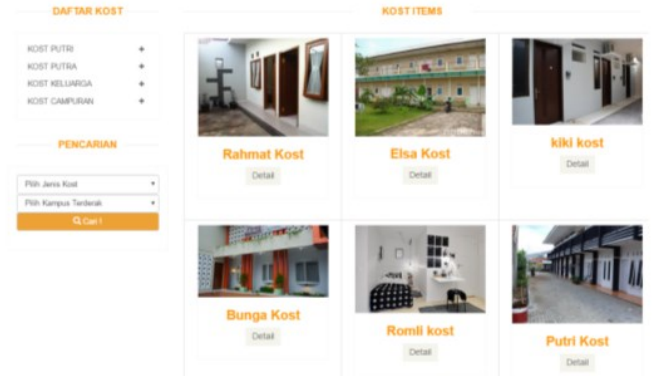

Gambar 5. Halaman Awal Pencari Kost 
Pada gambar dibawah Halaman utama ini memiliki beberapa Halaman yaitu profil pemilik, manajemen kost dan manajemen penyewaan.

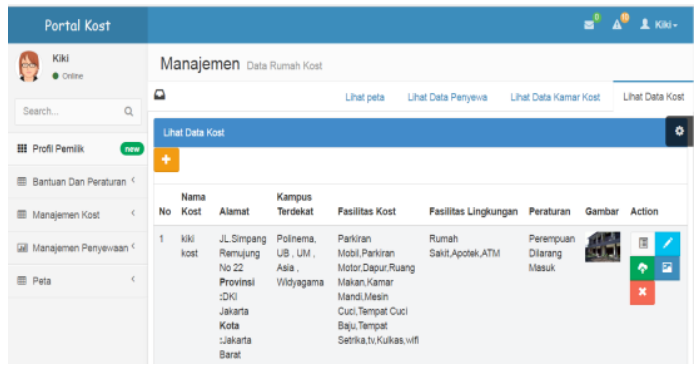

Gambar 6. HalamanTampilan Pemilik Kost.

Halaman awal setelah login pada pada admin portal kost akan tampil sebuah halaman seperti pada gambar dibawah. Halaman utama ini memiliki beberapa Halaman yaitu profil pemilik, manajemen kost dan manajemen penyewaan.

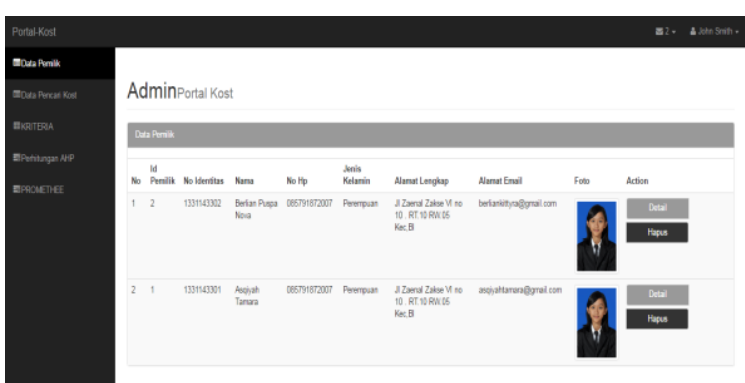

Gambar 7. HalamanTampilan Admin Portal Kost.

\subsection{Pembahasan}

Dari pengujian yang dilakukan, untuk pengujian fungsional dari setiap menu dan form sudah berjalan dengan baik. Dilihat dari proses pengujian, status uji dinyatakan berhasil untuk form dan setiap menu. Hal ini menunjukkan tingkat kesesuaian hasil pengujian fungsional sistem pendukung keputusan pemilihan rumah kost di kota malang berjalan sesuai dengan rancangan dan analisis yang telah dijelaskan pada tahap analisis kebutuhan. Pengujian hasil sistem dengan microsoft excel akan di uji dengan menghitung nilai bobot menggunakan metode ahp dan menghitung hasil untuk merekomendasi rumah kost menggunakan metode Promethee. Dalam pencarian bobot dengan perhitungan metode AHP

Table 3. Matriks perbandingan berpasangan

\begin{tabular}{|l|r|r|r|r|r|r|}
\hline Kriteria & \multicolumn{1}{|c|}{ Harga } & \multicolumn{1}{|c|}{$\begin{array}{l}\text { jarak } \\
\text { Kampus }\end{array}$} & Ukuran & fasilitas & \multicolumn{1}{l|}{ rs } & \multicolumn{1}{|c|}{$\begin{array}{l}\text { Dekat } \\
\text { Mall }\end{array}$} \\
\hline Harga & 1 & 9 & 9 & 9 & 9 & 9 \\
\hline $\begin{array}{l}\text { jarak } \\
\text { Kampus }\end{array}$ & 0,111 & 1 & 5 & 5 & 5 & 5 \\
\hline Ukuran & 0,11 & 0,2 & 1 & 3 & 3 & 3 \\
\hline Fasilitas & 0,111 & 0,2 & 0,333 & 1 & 1 & 1 \\
\hline Dekat rs & 0,111 & 0,2 & 0,333 & 0,333 & 1 & 2 \\
\hline $\begin{array}{l}\text { Dekat } \\
\text { Mall }\end{array}$ & 0,111 & 0,2 & 0,333 & 0,333 & 0,5 & 1 \\
\hline Total & 1,5556 & 10,8 & 16 & 18,667 & 21,5 & 23 \\
\hline
\end{tabular}

Setelah melakukan proses perebandingan berpasangan, dilanjutkan proses normalisasi pada metode ahp

Table 4 Normalisasi Matriks Secara Manual

\begin{tabular}{|l|c|c|c|c|c|c|}
\hline Kriteria & Harga & $\begin{array}{l}\text { jarak } \\
\text { Kampus }\end{array}$ & Ukuran & fasilitas & Rs & $\begin{array}{l}\text { Dekat } \\
\text { Mall }\end{array}$ \\
\hline Harga & 0,643 & 0,833 & 0,563 & 0,450 & 0,462 & 0,429 \\
\hline $\begin{array}{l}\text { jarak } \\
\text { Kampus }\end{array}$ & 0,071 & 0,093 & 0,313 & 0,250 & 0,256 & 0,238 \\
\hline Ukuran & 0,071 & 0,019 & 0,063 & 0,150 & 0,154 & 0,143 \\
\hline Fasilitas & 0,071 & 0,019 & 0,021 & 0,050 & 0,051 & 0,048 \\
\hline Dekat rs & 0,643 & 0,833 & 0,563 & 0,450 & 0,462 & 0,429 \\
\hline $\begin{array}{l}\text { Dekat } \\
\text { Mall }\end{array}$ & 0,071 & 0,019 & 0,021 & 0,050 & 0,051 & 0,095 \\
\hline Total & 0,071 & 0,019 & 0,021 & 0,050 & 0,026 & 0,048 \\
\hline
\end{tabular}

Setelah proses normalisasi matriks, dilakukan perhitungan nilai bobot yang do cari dengan pembagian jumlah kolom yang rumusnya adalah masing-masing cell dapat dilihat pada Tabel 5.

Tabel 5. Nilai Row Average atau Bobot

\begin{tabular}{|r|}
\hline Row Average \\
\hline 0,343 \\
\hline 0,182 \\
\hline 0,207 \\
\hline 0,141 \\
\hline 0,063 \\
\hline 0,064 \\
\hline
\end{tabular}

Setelah menghitung bobot menggunakan metode ahp, dilanjutkan dengan perhitungan menggunakan Promethee untuk mendapatkan hasil rekomendasi kost. Perhitungan Awal dari metode Promethee yaitu menghitung normalisasi dengan mengalikan nilai alternatif atau rumah kost dengan bobot yang di hasilkan dari metode ahp. Seperti tabel 6 di bawah.

Tabel 6. Normalisasi Pada Metode Promethee

\begin{tabular}{|l|l|l|l|l|l|l|}
\hline \multirow{2}{*}{ Kriteria } & \multicolumn{5}{|c|}{ Alterntif } & \multirow{2}{*}{ Tipe } \\
\cline { 2 - 6 } & $\mathbf{A 1}$ & $\mathbf{A 2}$ & $\mathbf{A 3}$ & $\mathbf{A 4}$ & $\mathbf{A 5}$ & \\
\hline F1 & 1,028 & 1,713 & 1,370 & 1,713 & 1,370 & Linier \\
\hline F2 & 0,365 & 0,547 & 0,547 & 0,729 & 0,547 & Linier \\
\hline F3 & 0,622 & 0,830 & 0,415 & 1,037 & 1,037 & Linier \\
\hline F5 & 0,564 & 0,423 & 0,564 & 0,705 & 0,564 & Linier \\
\hline F6 & 0,251 & 0,313 & 0,313 & 0,188 & 0,188 & Level \\
\hline
\end{tabular}

Setelah pencarian normalisasi pada metode promethee, dilakukan pencarian nilai threshold. Dapat dilihat pada Tabel 7. Setelah proses pencarian nilai threshold, dilakukan proses preferensi dan perhitungan promethee I dan Promethee 2. Yang dapat dilihat pada Tabel 8 . 
Tabel 7.Nilai Threshold

\begin{tabular}{|l|c|c|c|c|c|c|c|c|}
\hline Kriteria & Max & Min & min2 & K1 & K2 & V & Q & P \\
\hline F1 & 1,713 & 1,028 & 1,37 & 0,68 & 0,34 & 0,34 & 0,06 & 0,27 \\
\hline F2 & 0,729 & 0,365 & 0,54 & 0,36 & 0,18 & 0,18 & 0,03 & 0,14 \\
\hline F3 & 1,037 & 0,415 & 0,62 & 0,62 & 0,20 & 0,41 & 0,08 & 0,33 \\
\hline F4 & 0,705 & 0,423 & 0,56 & 0,28 & 0,14 & 0,14 & 0,02 & 0,11 \\
\hline F5 & 0,313 & 0,125 & 0,18 & 0,18 & 0,06 & 0,12 & 0,02 & 0,10 \\
\hline F6 & 0,32 & 0,19 & 0,25 & 0,12 & 0,06 & 0,06 & 0,01 & 0,05 \\
\hline
\end{tabular}

Tabel 8. promethee I

\begin{tabular}{|l|c|c|c|c|c|c|}
\hline Kost & G1 & G2 & G3 & G4 & G5 & $\begin{array}{l}\text { Leavi } \\
\text { ng } \\
\text { Flow }\end{array}$ \\
\hline G1 & 0 & 0,333 & 0,271 & 0,250 & 0,083 & 0,276 \\
\hline G2 & 0,438 & 0 & 0,500 & 0,000 & 0,167 & 0,276 \\
\hline G3 & 0,417 & 0,500 & 0 & 0,333 & 0,167 & 0,354 \\
\hline G4 & 0,667 & 0,521 & 0,667 & 0 & 0,500 & 0,589 \\
\hline Jumlah & 2,042 & 1,771 & 0,750 & 0,917 & 2,042 & \\
\hline $\begin{array}{l}\text { Entering } \\
\text { Flow }\end{array}$ & 0,505 & 0,510 & 0,443 & 0,188 & 0,229 & \\
\hline
\end{tabular}

Setelah itu melakukan perhitungan promethee 2 atau net flow dan melakukan proses perbandingan hasil perhitungan secara sistem dan excel, seperti pada tabel 9 .

Tabel 9.Perbandingan Hasil Perhitungan Net Flow secara sistem dan Excel

\begin{tabular}{|l|l|l|l|}
\hline No. & Kriteria & $\begin{array}{l}\text { Hasil Perhitungan } \\
\text { Manual (Excel) }\end{array}$ & $\begin{array}{l}\text { Hasil Perhitungan } \\
\text { Sistem }\end{array}$ \\
\hline 1. & G1 & 0,140432 & 0,140432 \\
\hline 2. & G2 & $-0,01852$ & $-0,01852$ \\
\hline 3. & G3 & $-0,09182$ & $-0,09182$ \\
\hline 4. & G4 & 0,04321 & 0,04321 \\
\hline 5. & G5 & $-0,11188$ & $-0,11188$ \\
\hline 6. & G6 & $-0,00309$ & $-0,00309$ \\
\hline 7. & G7 & 0,041667 & 0,041667 \\
\hline
\end{tabular}

Berdasarkan tabel perbandingan hasil Sistem dengan Microsoft Excel, didapatkan akurasi perangkingan berdasarkan perbandingan antara perhitungan manual (Excel) dengan perhitungan sistem adalah $100 \%$.

\section{Kesimpulan}

Dari pembahasan yang dijelaskan sebelumnya, dapat diperoleh beberapa kesimpulan sebagai berikut:

a. Aplikasi menyediakan bantuan dalam pemilihan Tempat Kost dimana pencari kost bisa melihat data kost secara online melalui sistem dan melakukan perbandingan sehingga calon pencari kost tidak perlu datang secara langsung ke tempat - tempat kost untuk melakukan perbandingan.

b. Aplikasi dapat melakukan perangkingan dan pemilihan Tempat Kost menggunakan metode AHP (Analytic Hierarchy Process) sebagai pencarian bobot yang konsisten, dilanjutkan dengan perhitungan menggunakan metode promethee untuk memberikan alternatif keputusan dalam melakukan pemilihan Tempat Kost di Kota Malang.

c. Berdasarkan hasil pengujian akurasi Sistem dengan Microsoft Excel, didapatkan akurasi perangkingan berdasarkan perbandingan antara perhitungan manual (Excel) dengan perhitungan sistem adalah $100 \%$. Akan tetapi dari 2 percobaan menggunakan bobot yang berbeda, menghasilkan rangking atau rekomendasi tempat kost yang sama , maka dapat disimpulkan bahwa penggunaan Metode AHP dan Promethee kurang sesuai dengan tujuan yang diharapkan sebelumnya.

\section{Daftar Pustaka:}

Aslam, Abang. 2010. Tertib Penghunian Perumahan (2: Dinas Perumahan Propinsi DKI Jakarta. [Online]Tersedia:https://id.scribd.com/doc/2807 8837/Tertib-Penghunian-Perumahan/

SHarsiti., dkk. Sistem Pendukung Keputusan Pemilihan Rumah Kost Di Sekitar Lingkungan Kampus Universitas Serang Raya Menggunakan Metode Analytical Hierarchy Proses (AHP). Jurnal Sistem Informasi Program Studi Sistem Informasi Fakultas Teknologi Informasi Universitas Serang Raya. ISSN: 2406-7768. 2015

Lemantara,Julianto., Dkk. Rancang Bangun Sistem Pendukung Keputusan Pemilihan Mahasiswa Berprestasi Menggunakan Metode AHP dan Promethee. Jurnal Sistem Informasi JNTETI, Vol. 2, No. 4. ISSN $2301-4156.2013$

Sundarraj R. P. A Web-Based AHP Approach To Standardize The Process Of Managing ServiceContracts. International Journal on Soft Computing (IJSC), Vol.2, No. 1. 2012 